\title{
Pengaruh Strategi Card Sort terhadap Hasil Belajar IPS ditinjau dari Sikap Sosial
}

\author{
H.Arrasyid ${ }^{1}$, I. W Lasmawan² ${ }^{2}$ A.A.I.N Marhaeni ${ }^{3}$ \\ 1,2,3 Program Studi Pendidikan Dasar, Program Pascasarjana Universitas Pendidikan Ganesha Singaraja, Indonesia
}

\author{
A R T I C L E I N F O \\ Article history: \\ Received 23 November \\ 2017 \\ Received in revised form \\ 12 Desember 2017 \\ Accepted 15 Januari 2018 \\ Available online 20 \\ Februari 2018

\section{Kata Kunci:} \\ Hasil belajar IPS, Sikap \\ Sosial, dan Strategi Card \\ Sort \\ Keywords: \\ Card Sort Strategies, Social \\ Attitude, and Social Study \\ Results
}

\begin{abstract}
A B STR A K
Penelitian ini bertujuan untuk mengetahui pengaruh Strategi Card Sort dan sikap sosial terhadap hasil belajar IPS siswa kelas V Gugus I Kecamatan Situbondo. Penelitian ini menggunakan metode eksperimen semu dengan menggunakan rancangan faktorial $2 \times 2$. Populasi dalam penelitian ini sebanyak 190 orang dan diambil sampel sebanyak 98 orang yang dipilih secara acak. Data dikumpulkan melalui test dan kuisioner. Analisis Data pada penelitian ini menggunakan analisis varians (Anava) dua jalan. Hasil penelitian menunjukan (1) Terdapat perbedaan hasil belajar IPS antara siswa yang mengikuti Strategi pembelajaran Card Sort dengan siswa yang mengikuti model pembelajaran konvensional. (2) Terdapat interaksi antara model pembelajaran dengan sikap sosial terhadap hasil belajar IPS. (3) Terdapat perbedaan hasil belajar IPS antara siswa yang mengikuti Strategi pembelajaran Card Sort dengan siswa yang mengikuti pembelajaran konvensional, pada siswa yang memiliki sikap sosial tinggi. (4) Tidak terdapat perbedaan hasil belajar IPS antara siswa yang mengikuti model Strategi pembelajaran Card Sort dengan siswa yang mengikuti model pembelajaran konvensional, pada siswa yang memiliki sikap sosial rendah.
\end{abstract}

\section{A B S T R A C T}

The pupose of this research investigate the effect of Strategy Card Sort on Social Studies Outcomes Reviewed from Students Social Attitude of Grade V at Group I district Situbondo. This research uses quasi-experimental method and $2 \times 2$ factorial design. The population in this research was 190 student and taken a sample 98 student selected randomly. Data collected used test and questionnaire. Data Analysis in this research used two way anova. The results showed (1) There are differences in learning outcomes between students who follow the Card Sort learning strategy with students who follow the conventional learning model. (2) There is an interaction between learning model and social attitude toward social study learning result. (3) There is a difference of social study learning outcomes among students who follow the Card Sort learning strategy with students who follow conventional learning metod, on students who have high social attitudes. (4) There is no difference in social study learning outcomes among students who follow the model of Card Sort learning strategy with students following the conventional learning model, in students with low social attitudes.

\footnotetext{
* Corresponding author.

E-mail addresses: harun.arrasyid@pasca.undiksha.ac.id (H. Arrasyid)
} 


\section{Pendahuluan}

Pendidikan menekankan pada interaksi antara guru dan siswa. Guru melakukan kegiatan mendidik, sedangkan siswa melakukan kegiatan belajar. Dengan demikian, pendidikan adalah proses interaksi yang mendorong terjadinya proses belajar. Upaya pendidikan ini tertuju agar tercapai perkembangan siswa ke arah kemandirian dan kedewasaaan baik secara jasmani maupun secara rohani. Pemerintah telah berupaya untuk memperbaiki kualitas pendidikan Indonesia diantaranya mensahkan UU No.20 Tahun 2003 tentang sistem pendidikan nasional. Pada pasal 3 Undang Undang tersebut menyatakan bahwa pendidikan bertujuan untuk berkembangnya potensi siswa agar menjadi manusia yang beriman dan bertakwa kepada Tuhan Yang Maha Esa, berakhlak mulia, sehat, berilmu, cakap, kreatif, mandiri, dan menjadi warga negara yang demokratis serta bertanggung jawab. Dengan demikian pendidikan haruslah secara terencana mengembangkan siswa melalui berbagai pengalaman belajar sehingga terbentuklah individu-individu yang dapat berperan dalam kehidupan di masa mendatang, baik untuk diri sendiri maupun bangsa dan negara.

Guru merupakan dasar penentu kualitas lulusan siswa. Maka sangat diperlukan kualitas guru yang profesional dalam proses perkembangan pendidikan. Guru dituntut tidak hanya pintar dalam penguasaan materi pelajaran, tetapi juga diharapkan mampu mengelola kelas dengan baik supaya proses pembelajaran berjalan dengan aktif, inovatif, kreatif, efektif, dan menyenangkan (Jauhar, 2011). Menurut Wahab (dalam Sariani, 2016) guru sebagai pelaksana pendidikan harus mampu mendorong siswanya untuk berfikir kritis, kreatif dan memiliki sikap disiplin pribadi agar di dalam melaksanakan hak-hak dan kewajiban di dasari oleh pengetahun dan didukung oleh keterampilan agar dapat berpartisipasi dengan baik dalam masyarakat. Untuk meningkatkan keterampilan sikap ini guru harus memberikan pembelajaran yang bermakna. Pembelajaran bermakna tidak dapat diberikan hanya dengan menggunakan metode, teknik, strategi konvensional saja. Tetapi seorang guru harus kreatif dalam menyajikan pembelajaran terhadap siswanya. Khususnya dalam pembelajaran IPS penggunaan model, metode, starategi dan teknik pembelajaran sangat dibutuhkan. IPS di sekolah dapat didefinisikan sebagai program pendidikan yang mengintegrasikan ilmu-ilmu sosial, humaniora, idiologi negara dan agama yang disusun melalui pendekatan pendidikan dan pertimbangan psikologis serta kebermaknaanya bagi siswa dalam kehidupannya (Kertih, 2012).

Pembelajaran IPS di sekolah bukanlah untuk membentuk siswa menjadi ahli IPS melainkan sebagai bekal pada jenjang selanjutnya. Penggunaan Strategi pembelajaran yang tepat dibutuhkan dalam mengajarkan IPS agar pembelajaran IPS lebih bermakna bagi siswa. Dengan pembelajaran yang bermakna maka apa yang dipelajari siswa akan tetap melekat di ingatan siswa. Strategi pembelajaran dapat diartikan sebagai perencanaan yang berisi tentang rangkaian kegiatan yang didesain untuk mencapai tujuan tertentu (Marhaeni, 2013). Untuk mendukung tujuan IPS yaitu sebagai bekal siswa pada jenjang selanjutnya maka guru harus menggunakan strategi yang tepat dalam mengajarkan pembelajaran IPS diskolah. Namun pada kenyataannya dalam pembelajaran di kelas dihadapkan pada masalah yang menghambat keberhasilan proses pembelajaran. Proses pembelajaran yang berlangsung selama ini yaitu siswa cenderung duduk, diam dan hanya mendengarkan tanpa memberikan respon yang relevan dengan materi belajar, selain itu guru merupakan satu-satunya sumber belajar tunggal bagi siswa dan hanya sedikit guru yang memiliki kompetensi sesuai bidangnya. Kecenderungan ini menjadi kendala bagi guru karena mengakibatkan ketercapaian penguasaan materi yang rendah pada siswa. Hal ini menjadi tolak ukur kualitas pendidikan di Indonesia.

Pada praktik di lapangan guru masih cenderung menggunakan strategi pembelajaran konvensional. Pada pembelajaran konvensional perserta didik lebih banyak mendengarkan dan mengerjakan tugas jika guru memberi latihan soal. Hal ini tidak menjadikan pembelajaran yang bermakna bagi siswa. Oleh karena itu diperlukan suatu strategi pembelajaran yang dapat mencapai tujuan pembelajaran agar suatu pembelajaran dapat bermakna bagi siswa. Menurut Bruner dalam (Marhaeni, 2013) belajar akan lebih bermakna bagi siswa jika mereka memusatkan perhatiannya untuk memahami struktur materi yang dipelajari. Selain itu penggunaan strategi pembelajaran yang baik diharapkan dapat memberikan peningkat hasil belajar siswa. Untuk memberikan pembelajaran IPS yang bermakna sehingga berimbas pada hasil belajar siswa dibutuhkan suatu strategi yang tepat dalam suatu pembelajaran. Peneliti merujuk suatu strategi pembelajaran aktif yaitu Card Sord. Strategi pembelajaran Card Sort merupakan aktivitas kerjasama yang bisa digunakan untuk mengajarkan konsep, karakteristik klasifikasi, fakta tentang benda, atau menilai informasi (Siberman, 1996). Strategi Card Sort memberikan interaksi antar siswa dalam kelas yang artinya terdapat keterampilan sikap pada siswa untuk melakukan interaksi. Interaksi antar siswa tersebut dapat juga disebut dengan sikap sosial. Maka dari itu jika siswa memiliki sikap sosial yang baik diharapkan dapat beriteraksi dengan siswa lainya sehingga dapat meningkatkan hasil belajar siswa. 


\section{Metode}

Metode penelitian yang digunakan adalah eksperimen semu, penelitian ini melibatkan dua kelompok, yaitu kelompok kontrol dan kelompok eksperimen yang mana penelitian ini akan mengamati dan meneliti tentang hasil belajar IPS pada Kurikulum 2013.Untuk menentukan hasil belajar IPS pada Kurikulum 2013 pada kelompok eksperimen maupun pada kelompok kontrol dilakukan dengan memberikan tes mata pelajaran IPS pada Kurikulum 2013. Rancangan analisis data dalam penelitian menggunakan rancangan faktorial $2 \times 2$. Terdapat enam sekolah yang akan menjadi populasi dalam penelitian ini. Populasi dalam penelitian ini dilakukan pada kelas $V$ yang terdapat pada enam sekolah tersebut. Keenam sekolah itu merupakan gugus satu yang terdapat di Kabupaten Situbondo, Kecamatan Situbondo. Setelah melakukan uji kesetaraan langkah selanjutnya yaitu melakukan pengundian untuk menentukan kelas kontrol dan kelas eksperimen. Dari pengundian yang telah dilakukan diperoleh sampel penelitian yaitu SDI Al-Abror kelas VA,VB, dan VD sebagai kelas kontrol dan sebagai kelas eksperimen yaitu SDN 6 Dawuhan dan SDN 2 Patokan kelas VA dan VB.

Penelitian ini melibatkan beberapa variabel yang dapat dikelompokkan sebagai berikut. Variabel terikat adalah variabel akibat yang akan berubah mengikuti penerapan variabel bebas. Dalam hal ini variabel terikat adalah hasil belajar siswa. Variabel bebas adalah variabel yang dikembangkan peneliti. Dalam penelitian ini variabel bebasnya adalah Strategi Pembelajaran Card Sort. Variabel moderator adalah variabel yang mengendalikan variabel bebas. Dalam penelitian ini variabel moderatornya adalah Sikap sosial. Untuk mengumpulkan data Sikap sosial siswa dipergunakan kuesioner Sikap sosial. Untuk mengukur hasil belajar IPS digunakan instrument tes hasil belajar. Tes hasil belajar ini berupa tes pilihah ganda (obyektif) terdiri dari 4 pilihan jawaban : Tes ini disusun oleh peneliti dengan berpedoman pada Kurikulum 2013. Analisis data yang digunakan pada penelitian ini analisis statistik deskriptif, yang artinya bahwa data dianalisis dengan menghitung nilai rata-rata, modus, median, standar deviasi, varian, skor maksimum, dan skor minimum. Dalam penelitian ini data disajikan dalam bentuk grafik histogram. Teknik yang digunakan untuk menganalisis data guna menguji hipotesis penelitian adalah Two Way Anova. Sebelum dilakukan analisis data, maka dilakukan uji normalitas sebaran data dengan menggunakan uji Kolmogorov-smirnov, uji homogenitas varians dengan uji Levene's.

\section{Hasil dan Pembahasan}

Perbedaan Hasil Belajar IPS antara Kelompok Siswa yang Mengikuti dengan Strategi pembelajaran Card Sort dengan Kelompok Siswa yang Mengikuti dengan Pembelajaran Konvensional. Berdasarkan hasil analisis data yang telah membuktikan bahwa terdapat perbedaan hasil belajar IPS siswa yang mengikuti model Strategi pembelajaran Card Sort dengan hasil belajar IPS siswa yang mengikuti pembelajaran konvensional. Hal ini ditunjukkan dengan koefisien Anava (F) sebesar 46,957 yang ternyata signifikan. Selanjutnya terbukti berdasarkan hasil penelitian bahwa skor rata-rata hasil belajar IPS siswa yang mengikuti model Strategi pembelajaran Card Sort sebesar 82,04 lebih tinggi dari pada siswa yang mengikuti strategi pembelajaran konvensional dengan nilai rata-rata hasil belajar IPS sebesar 73,62. Jadi dalam perbandingan antara Strategi pembelajaran Card Sort dengan pembelajaran konvensional, terdapat pengaruh signifikan terhadap hasil belajar IPS siswa. Dalam pembelajaran IPS, proses kegiatan belajar siswa dengan menerapkan Strategi pembelajaran Card Sort menyenangkan untuk siswa, serta siswa lebih termotivasi untuk kreatif dan berkreasi dalam belajar IPS dibandingkan dengan pembelajaran konvensional. Aktivitas kegiatan belajar siswa berdasarkan Strategi pembelajaran Card Sort. Hal ini disebabkan salah satunya karena Strategi pembelajaran Card Sort memacu siswa agar saling mendorong dan membantu satu sama lain untuk menguasai keterampilan IPS melalui pembelajaran yang dirancang sedemikian rupa berdasarkan karakteristik Strategi pembelajaran Card Sort sehingga siswa dapat merespon informasi atau konsep pembelajaran dengan baik dan optimal selama kegiatan pembelajaran IPS berlangsung. Sebagaimana menurut siberman (2016), Card Sort merupakan aktivitas kerjasama yang digunakan untuk mengajarkan konsep, karakteristik klasifikasi, fakta tentang benda, atau melalui informasi.

Dari uraian diatas Kegiatan pembelajaran menggunakan strategi pembelajaran Card Sort dirasakan lebih nyaman, rileks dan berkonsentrasi dalam belajar, siswa merasa tidak cepat jenuh mampu meningkatkan fungsi otak kerja dalam merespon informasi. Selain itu dengan strategi Card Sort mampu mengkondisikan siswa untuk saling mendorong anggota kelompok untuk berpartisipasi dalam pembelajaran. Dengan adanya rasa senang pada diri siswa dan rasa siap untuk belajar IPS merupakan dasar untuk mengoptimalkan kemampuan siswa untuk meraih hasil belajar IPS yang lebih baik. Didukung dengan penelitian yang telah dilakukan sebelumnya oleh Syakdiah (2016), siswa merasa nyaman dengan penerapan sintaks Card Sort dalam pembelajaran, hal tersebut dibuktikan dari nilai hasil belajar yang 
mengalami kenaikan pada siklus I dan II. Terkait dengan penelitian yang dilakukan Syakdiah, Lestari (2014) menyimpulkan terdapat perbedaan yang signifikan antara kemampuan josuushi siswa yang menggunakan strategi pembelajaran aktif tipe card sort dengan siswa yang menggunakan metode konvensional (ceramah) dalam pembelajaran. Sejalan dengan teori siberman (2016) gerak fisik yang terjadi akibat penerapan strategi Card Sort dapat menghilangkan rasa penat dalam diri siswa. Artinya gerak fisik saat siswa melakukan kegiatan pembelajaran yang berdasarkan Strategi Card Sort menghilangkan rasa jenuh siswa terhadap pembelajaran.

Terdapat Interaksi Antara Kelompok Strategi pembelajaran Card Sort dengan Sikap Sosial, Pengaruhnya terhadap Hasil Belajar IPS Siswa. Hasil uji hipotesis kedua menunjukkan bahwa $\mathrm{F}=56,77$ dengan signifikansi $(\mathrm{sig})=0,000$. Nilai signifikansi jauh lebih kecil dari pada nilai signifikansi yang ditentukan yakni 0,05 . Oleh karena itu, hipotesis Ho ditolak dan H1 diterima. Artinya, terdapat pengaruh interaksi antara strategi pembelajaran dengan sikap sosial terhadap hasil belajar IPS. Hasil penelitian ini menunjukkan bahwa interaksi antara Strategi pembelajaran Card Sort dan sikap sosial tinggi lebih optimal. Sedangkan kelompok siswa yang memiliki sikap sosial rendah yang mengikuti pembelajaran dengan Strategi pembelajaran Card Sort memiliki hasil belajar IPS sedikit lebih rendah. Newcomb (dalam Notoatmodjo, 2003) mengemukakan bahwa sikap merupakan kesiapan atau kesediaan untuk bertindak, dan bukan merupakan pelaksana motid tertentu. Strategi Card Sort memberikan pembelajaran yang mengharuskan siswa untuk berinteraksi dengan siswa lainnya dengan bentuk pembelajaran berkelompok. Sejalan pendapat Bialangi (2016) "Social interactions in the group discussion are able to construct students' knowledge" artinya interaksi sosial dalam kelompok mampu membangun pengetahuan siswa. interaksi yang terjadi antar siswa saat melakukan kegiatan pembelajaran menggunakan strategi Card Sort yaitu ketika siswa dikelompokkan setelah mengambil kartu indeks. Rahmaningrum (2016) strategi ini merupakan aktivitas kerjasama yang bisa digunakan untuk mengajarkan konsep, karakteristik klasifikasi, fakta tentang benda, atau menilai informasi. Dalam hal ini Siswa dengan sikap sosial tinggi lebih siap untuk mengikuti pelajaran menggunakan strategi Card Sort. Berbeda dengan siswa yang mempunyai sikap sosial rendah mengikuti pembelajaran menggunakan pembelajaran Card Sort nilai mereka cenderung kecil disebabkan siswa tidak siap dalam mengikuti pembelajaran Card Sort sehingga berpengaruh pada hasil belajar siswa. Hal ini didukung oleh penelitian yang telah dilakukan Witariani (2014) bahwa terdapat intertaksi antara model pembelajaran dengan sikap sosial terhadap hasil belajar siswa.

Dari penjelasan diatas, terdapat interaksi antara Strategi Card Sort dan sikap sosial siswa yang berpengaruh terhadap hasil belajar siswa. Pengaruh sikap sosial hanya pada penggunan strategi pembelajaran yang mengharuskan siswa berkolaborasi atau berkelompok, hal ini menerangkan bahwa pemilihan model, metode, dan strategi pembelajaran haruslah melihat kecocokan antara keadaan siswa dan pelajaran yang akan digukan.

Terdapat Perbedaan Hasil Belajar IPS yang Mengikuti Pembelajaran Strategi Card Sort Dengan Pembelajaran Strategi Konvensional Pada Siswa yang Memiliki Siakap Sosial Tinggi. Berdasarkan uji tscheff di dapat thitung sebesar 10,5 sedangkan tabel dengan taraf signifikansi 0,05 sebesar 3,19. Hal ini berarti nilai thitung $>$ ttabel $(10,5>3,19)$ sehingga $\mathrm{H}_{0}$ ditolak dan $\mathrm{H}_{1}$ diterima. Ini berarti bahwa Siswa dengan sikap sosial tinggi, hasil belajar peseta didik yang mengikuti pelajaran menggunakan strategi Card Sort lebih baik dari hasil belajar Siswa yang mengikuti pelajaran menggunakan pembelajaran konvensional. Pada siswa yang memiliki sikap sosial tinggi dengan diberikan perlakuan strategi Card Sort menjadikan pembelajaran bersifat student centered, dalam pembelajaran yang bersiafat studen centered terdapat interaksi sosial pada siswa yang dibutuhkan untuk mengkontrusi pengetahuan sediri. Adanya interaksi sosial tersebut yang menjadi dasar kecocokan sikap sosial dengan strategi pembelajaran Card Sort dalam meningkatkan hasil belajar siswa. Sejalan menurut Sanjaya (2016) juga berpendapat strategi pembelajaran Card Sort merupakan kegiatan kolaboratif yang digunakan pendidik untuk mengajak peserta didik menemukan konsep dan fakta melalui klasifikasi materi yang akan dibahas dalam pembelajaran. Didukung penelitian yang dilakukan wardana (2015) Terdapat perbedaan signifikan terhadap hasil belajar PKn antara siswa yang mengikuti model pembelajaran Resolusi Konflik Bermuatan Multikultur dengan siswa yang mengikuti model pembelajaran konvensional pada siswa yang mempunyai sikap sosial tinggi. Terkait dengan kontribusi sikap sosial, penelitian yang juga dilakukan oleh Setiawati (2015) Untuk siswa yang memiliki sikap sosial tinggi, ada perbedaan hasil belajar PKn antara siswa yang mengikuti pelajaran dengan model pembelajaran kooperatif tipe numbered head together dan siswa yang mengikuti pelajaran dengan model pembelajaran konvensional pada siswa kelas V gugus IV Manggis. Berbeda dengan siswa yang memiliki sikap sosial tinggi dan mendapat perlakukan pembelajaran konvensional. Pembelajaran konensional cenderung bersifat teacher centered yang artinya pembelajaran lebih terfokus pada guru yang menjadikan minimnya interaksi sosial pada siswa, hal ini yang menjadi 
dasar ketidak cocokan pembelajaran konvensional siswa yang memiliki sikap sosial tinggi, sehingga hasil belajar siswa cenderung kecil.

Tidak Terdapat Perbedaan Hasil Belajar IPS yang Mengikuti Pembelajaran Strategi Card Sort Dengan Pembelajaran Strategi Konvensional Pada Siswa yang Memiliki Siakap Sosial Rendah. Dari hasil perhitungan di dapat thitung sebesar 0,58 sedangkan tabel dengan taraf signifikansi 0,05 sebesar 3,19. Hal ini berarti nilai thitung $<\mathrm{t}_{\text {tabel }}(0,58<3,19)$. sehingga $\mathrm{H}_{0}$ diterima dan $\mathrm{H}_{1}$ ditolak. Ini berarti bahwa Siswa dengan sikap sosial rendah, hasil belajar peseta didik yang mengikuti pelajaran menggunakan strategi Card Sort tidak lebih baik dari hasil belajar Siswa yang mengikuti pelajaran menggunakan pembelajaran konvensional. Hal ini dikarenakan siswa yang memiliki sikap sosial rendah dengan perlakuan strategi pembelajaran Card Sort tidak tebiasa dengan pembelajaran yang bersifat Student Center karena siswa dengan sikap sosial rendah cenderung memiliki interaksi sosial yang rendah. hal ini berbeda dengan pembelajaran konfensional yang bersifat Teacher Center, dalam pembelajaran Teacher Center minim terdapat interaksi sosial pada siswa, ini yang mendasari pembelajaran konvensional lebih baik daripada pembelajaran menggunakan strategi Card Sort dalam meningkatan hasil belajar.

Berdasarkan fakta yang didapat dari hasil penelitian, sikap sosial memberikan kontribusi positif dan negatif pada masing-masing pembelajaran. Seperti halnya penelitian dalam Wardana (2015) Terdapat perbedaan signifikan terhadap hasil belajar PKn antara siswa yang mengikuti model pembelajaran Resolusi Konflik Bermuatan Multikultur dengan siswa yang mengikuti model pembelajaran konvensional pada siswa yang mempunyai sikap sosial rendah. dalam penelitian tersebut dijelaskan bahawa sikap sosial berkontribusi terhadap model/strategi pembelajaran yang digunakan. Terkait dengan kontribusi sikap sosial, penelitian yang juga dilakukan oleh Setiawanti (2015) Untuk siswa yang memiliki sikap sosial rendah, ada perbedaan hasil belajar PKn antara siswa yang mengikuti pelajaran dengan model pembelajaran kooperatif tipe numbered head together dan siswa yang mengikuti pelajaran dengan model pembelajaran konvensional pada siswa kelas V gugus IV Manggis. Selain itu terkait dengan pengaruh sikap sosial rendah, Sukerteyasa (2014) pada kelompok siswa yang memiliki sikap sosial rendah, prestasi belajar PKn siswa yang mengikuti pembelajaran dengan metode diskusi kelompok berbasis asesmen diri lebih rendah daripada siswa yang mengikuti pembelajaran dengan metode dan asesmen konvensional.

Sejalan dengan teori yang ada, Sikap adalah kesadaran individu yang menentukan perbuatan yang nyata dalam kegiatan sosial, Ahmadi (dalam Kusuma, 2017). Newcomb (dalam Notoatmodjo, 2003) mengemukakan bahwa sikap merupakan kesiapan atau kesediaan untuk bertindak, dan bukan merupakan pelaksana motid tertentu. Artinya sikap sosial rendah cenderug nengarahkan siswa pada kegiatan yang memiliki interaksi rendah dalam pembelajaran, serta dengan sikap sosial yang rendah siswa cenderung lebih siap dalam mengikuti pembelajaran IPS berbentuk konvensional.

\section{Simpulan Dan Saran}

Berdasarkan temuan di atas, dapat disimpulkan bahwa (1) Terdapat perbedaan hasil belajar IPS antara siswa yang mengikuti Strategi pembelajaran Card Sort dengan siswa yang mengikuti model pembelajaran konvensional. (2) Terdapat interaksi antara model pembelajaran dengan sikap sosial terhadap hasil belajar IPS. (3) Terdapat perbedaan hasil belajar IPS antara siswa yang mengikuti model Strategi pembelajaran Card Sort dengan siswa yang mengikuti pembelajaran konvensional, pada siswa yang memiliki sikap sosial tinggi. (4) Tidak terdapat perbedaan hasil belajar IPS antara siswa yang mengikuti model Strategi pembelajaran Card Sort dengan siswa yang mengikuti model pembelajaran konvensional, pada siswa yang memiliki sikap sosial rendah.

Berdasarkan temuan yang telah dipaparkan pada pembahasan, maka beberapa saran dapat dianjurkan sebagai berikut (1) Mengingat keterbatasan pada penelitian ini, perlu dilakukan penelitian yang lebih lanjut. Sehingga diharapkan penelitian dengan variabel yang sama mendapatkan hasil yang lebih baik dari penelitian sebelumnya, dan sebagai bahan pertimbangan untuk perbaikan dan penyempurnaan penelitian yang akan dilaksanakan. (2) Guru dalam menyampaikan materi pelajaran di kelas disarankan agar lebih kreatif dan berinovasi dalam memilih model pembelajaran yang mana model pembelajaran yang dipilih nantinya mampu mengatasi kebutuhan belajar dan karakteristik siswa. (3) Peneliti lain yang akan mengadakan penelitian dalam meningkatkan hasil belajar IPS, agar mempertimbangkan variabel-variabel lain seperti bakat, motivasi, intelegensi dan lain sebagainya serta menggunakan Strategi pembelajaran yang lain untuk alternative di dalam meningkatkan hasil belajar IPS sehingga khasanah kajian terhadap hasil belajar IPS menjadi lebih bervariasi lagi. 


\section{Daftar Rujukan}

Bialangi, M. S., et al. 2016. "Development of students' social attitudes in biology classroom through jigsaw and guided inquiry". International Journal of Academic Research and Development. 1(10), pp. 1-7, ISSN 2455-4197.

Dantes, N. 2012. Metode Penelitian. Singaraja: Universitas Pendidikan Ganesha.

Dwi Sariani, N. K, dkk. 2016. Pengaruh Model Pembelajaran Value Clarification technique(CVT) terhadap Sikap Sosial dan Hasil belajar mata pelajaran PKn Pada Siswa Kelas IV SD. e-jurnal PGSD Universitas pendidikan Ganesha, 4(1), pp.

Jauhar, M. 2011. Implementasi PAIKEM dari Behavioristik Sampai Konstruktivistik. Jakarta: Prestasi Jaya.

Kertih, I. W. 2012. Pendidikan IPS: Apa, Mengapa, dan Bagaimana. Tugas Forotofolio. Disusun untuk Memenuhi Tugas Akhir Mata Kuliah Siminar Masalah-masalah Pendidikan IPS Universitas Pendidikan Indonesia. Desember 2012.

Komang Witariani, I.A., dkk. 2014. "Implementasi Pendekatan Pembelajaran Kooperatif Tipe Jingsaw Terhadap Prestasi Belajar IPS ditinjau dari Sikap Sosial Siswa Kelas VII SMPN 12 Denpasar". $\boldsymbol{e}$ jurnal Program Pascasarjana Universitas Pendidikan Ganesha, 5(1).

Kusuma, P. I., dkk. 2017. Pengaruh Model Pembelajaran Resolusi Konflik Terhadap Hasil Belajar PKn Ditinjau Dari Sikap Sosial Siswa Kelas V SD Gugus Kolonel I Gusti Ngura Rai Denpasar Utara. Jurnal Ilmiah Pendidikan dan Pengaharan Universitas Pendidikan Ganesha. 14(3).

Lestari, N., dkk. 2015. Penerapan Strategi Pembelajaran Aktif Tipe Card Sort Untuk Meningkatkan Kemampuan Belajar Siswa Pada Pokok Bahasan Josuushi Kelas XI SMA Taruna Pekanbaru. Jurnal Universitas Pekanbaru.

Marhaeni, A.A.I.N. 2013. Landasan dan Inovasi Pembelajaran: Materi Kuliah Untuk S2 Pendidikan Dasar. Singaraja: Undiksha.

Notoatmodjo, S. 2003. Pendidikan Dan Prilaku Kesehatan. Jakarta: Rineka Cipta

Rahmatiningrum, M., dkk. 2016. Peningkatan Hasil Belajar IPS Melalui Strategi Pembelajaran Aktif Card Sort Siswa Kelas V. Jurnal Pendidikan Guru Sekolah Dasar. 9(5), pp. 913-921.

Sakdiyah, H. S.,dkk. 2016. Penerapan Model Pembelajaran Card Sort Untuk Meningkatkan Keaktifan Siswa Kelas V Se-Gugus Kebonsari Kecamatan Sukun Kota Malang. Jurnal Pendidiakan: Teori, Penelitian dan Pengembangan, 1(10), pp. 2004-2009.

Sanjaya, I. K. 2016. Penerapan Strategi Pembelajaran Card Sort Untuk Meningkatkan Aktivitas dan Hasil Belajar IPA. e-jurnal PGSD Universitas Pendidikan Ganesha. Mimbar PGSD. 6(3), pp.

Setiawati, Y., dkk. 2015. "Pengaruh Model Pembelajaran Kooperatif Tipe Numbered Head Together(NHT) terhadap hasil belajar PKn ditinjau dari Sikap Sosial Siswa Kelas V di Gugus IV Manggis. e-jurnal Program Pascasarjana Universitas Pendidikan Ganesha, 5(1).

Siberman, M. L (Eds). 2016. Active learning:101 cara belajar siswa aktif. Terjemahan Raisul Muttaqien. 1996. Active Learning: 101 Strategies to Teach Any Subject. Bandung: Nuansa.

Sukertayasa, I. P., dkk. 2014. “ pengaruh Pengaruh Penerapan Metode Diskusi Kelompok Berbasis Asesmen Diri (Selfasessment) Dan Sikap Sosial Terhadap Prestasi Belajar Pkn Siswa Kelas XI SMK Negeri 4 Denpasar". e-jurnal Program Pascasarjana Universitas Pendidikan Ganesha, 4(1) ,pp.

Undang-Undang Republik Indonesia Nomor 20 Tahun 2003 Tentang Sistem Pendidikan Nasional. 2003. Jakarta: Kementerian Pendidikan dan Kebudayaan. 
Wardana, I. P. K., dkk. 2015. "Pengaruh Implementasi Model Pembelajaran Resosuli Konflik Bermuatan Multikultur Terhadap Hasil Belajar PKn Ditinjau Dari Sikap Sosial Siswa Pada Kelas VII SMP Negeri 10 Denpasar". e-jurnal Program Pascasarjana Universitas Pendidikan Ganesha, 6(1), pp. 